\title{
Strategies for distance support of advanced professional training for teachers of Russian as the second language
}

\author{
Alina Aleksandrovna Pozdnyakova ${ }^{11}$, Galina Vasilievna Kuznetsova ${ }^{1}$, Tatiana Evgenievna \\ Kolyadina $^{1}$, Daria Aleksandrovna Dmitrieva $^{1}$, and Larisa Yurievna Morozova ${ }^{2}$ \\ ${ }^{1}$ The Kosygin State University of Russia, Institute of International Education, Moscow, Russia \\ ${ }^{2}$ Moscow State Pedagogical University, Institute of International Education, Moscow, Russia
}

\begin{abstract}
The effectiveness of advanced professional training for a teacher of Russian as the second language is possible only based on the complex use of modern distance learning technologies that are aimed at usage in a specific subject area and reflect its specifics as adequately as possible. This article summarizes the results of project activities on the formation of a system of advanced professional education for teachers of Russian as the second language, carried out at the premises of The Kosygin State University of Russia. The project aimed to develop strategies for creating an integrated system of distance support, including 1) a model of an electronic educational environment based on cloud technologies and representing a secure solution in a controlled segment of the Internet, capable of accumulating resources for teaching the Russian language in Russia and abroad; 2) a system of diagnostic measures to identify the competence gaps of RSL (Russian as the Second Language) teachers in the subject, organizational, methodological, psychological spheres; 3) recommendations for the creation of advanced training programs (modules) capable of eliminating the identified competence deficiency in these areas. The following can be considered as objectives of the project: 1) selection of distance technologies (elements of distance technologies), relevant for use in the process of professional training of an RSL teacher; 2) formation of a cluster of diagnostic measures; 3) modeling educational content; 4) determination of cognitive strategies for teaching and self-education of an RSL teacher in the system of advanced professional training. The system of diagnostic measures described in the work assumed the assessment (measurement) of the teacher's activities in three aspects: 1) from the standpoint of subject knowledge, 2) from the organizational and methodological standpoint, 3) from the psychological standpoint. This approach made it possible to single out the components of professional competencies and form a methodology for expert assessment of the educational environment, including the Russian-speaking educational environment abroad. In this case, the instrument of pedagogical measurement was testing carried out remotely on the constantly operating platform of The Kosygin State University of Russia at https://edu.rguk.ru.

Keywords: diagnostic testing, distance technologies, electronic learning environment (ELE), Russian as the second language (RSL)
\end{abstract}

${ }^{1}$ Corresponding author: apozdnyakova@live.ru 


\section{Introduction}

The effectiveness of advanced professional training of a teacher today largely depends on whether he has competencies in the field of distance technologies, including those related to a specific area of subject knowledge. Training of teachers of Russian as the second language in the latest distance and information and telecommunication technologies is possible only if an electronic learning environment (ELE) and an integrated, systematic organization of the learning process are formed. The mechanism for creating an ELE and its components (diagnostic unit), developed at The Kosygin State University of Russia in the framework of the project for distance support of advanced professional training for teachers of RSL are the subject of this article.

The goal of the project was to develop strategies for creating an integrated system of distance support, including 1) a model of an electronic learning environment (ELE); 2) a system of diagnostic measures to identify the competence gaps of RSL teachers in the subject, organizational, methodological, and psychological spheres; 3) recommendations for the creation of programs (modules) of advanced training courses that can eliminate the identified competence deficiency in these areas.

The following can be considered the objectives of the project: 1) selection of distance technologies (elements of distance technologies), relevant for use in the process of professional training of an RSL teacher; 2) formation of a diagnostic measures cluster; 3) modeling educational content; 4) determination of cognitive strategies for teaching and self-education of the teacher of the Russian language.

The use of an ethnic-oriented approach to the advanced professional training of an RSL teacher, as well as taking the specifics of the contingent of trainees into account, makes it possible to determine the individual trajectories of the teacher's professional development.

These strategies are implemented under the new requirements for the professional activity of a higher school teacher in the distance learning system [1] and in the framework of solving the problems of the national "Digital Economy of the Russian Federation" [2] program.

\section{$2 \quad$ Methods}

The goals and objectives of the project determined the use of such methods as theoretical analysis of the literature of psychological, pedagogical, sociological and cultural orientation; studying the practice of implementing different types of diagnostic measures (questioning, testing, interviewing, etc.) used to assess the realities of the education sector in Russia and abroad. Special attention was paid to distance forms of diagnosis and control [3-5]; analysis of expert opinions and procedures for assessing the quality of online education [3]; analysis of statistical data [6-8].

The concept of diagnostic measures is based on the provisions of the theory of needs and information by Simonov [9] and the personal and activity approach to teaching by Galperin and Talyzina [10-12], adapted to analyze the interaction of subjects in the digital information environment. The work of Dan Douglas on language for specific purposes (LSP) and methods of organizing test control has been extremely useful for the formation of diagnostic tests corpus [13-14]; as well as works by O'Keeffe [15-16], McCarthy [15-16], Carter [15], analyzing the principles of creating contextual tests. The use of distance technologies, described in the studies of Richards and Rogers [17], White [18], Thorne [19], Helm [20- 21], Wong and Li [22], as well as Cooch [23], helped in the creation of electronic materials for distance testing of teachers of Russian as the second language. The 
methodology for the expert assessment of the Russian-speaking educational environment abroad, developed within the framework of the project, made it possible to analyze the orientation of the educational content of the Russian school concerning the formed competencies of the students. The created digital expert toolkit was tested in practice while carrying out diagnostic activities in Russian schools abroad.

\section{$3 \quad$ Results}

The main result of the study is the creation of a project of an electronic learning environment (ELE) based on cloud technologies that represent a secure solution in a controlled segment of the Internet, capable of accumulating resources for teaching Russian as the second language in Russia and abroad. A permanent platform https://edu.rguk.ru of The Kosygin State University of Russia was chosen for project implementation.

The purpose of creating an electronic learning environment is to improve the quality of teaching RSL through the wide and effective implementation of e-learning, providing the process of advanced professional training of teachers with accessible information and educational resources, means of automated control of the processes of diagnosing professional competencies [24].

It is planned to create a special structure - the Center for the professional adaptation of Russian language teachers in foreign schools - within the framework of the project. The functioning of such a center will allow updating the content, conducting systematic professional diagnostics, and training teachers of RSL.

Based on the analysis of test results and identification of deficiencies in professional competencies, it is planned to develop programs of advanced professional training as well as to conduct advanced training courses on the developed programs using distance learning technologies.

The implementation of the project allows:

1) identifying and assessing the level of proficiency in the subject, methodological, psychological, pedagogical, and other competencies among teachers of Russian as the second language in Russia and abroad;

2) developing a strategy for correcting professional competencies (subject, methodological, psychological) of teachers of Russian as the second language;

3 ) ensuring systematic productive interaction with this category of teachers through the functioning of a new structure - the Center for the Professional Adaptation of Russian Language Teachers of Foreign Schools.

The implementation of the project also makes it possible to inform teachers about the best methodological experience regarding the language training of students living outside the Russian Federation in more detail.

The results of the project are applicable in further activities: 1) in the field of protection, support, and development of the Russian language and education in Russian; 2) in the activities of educational organizations in different countries.

The implementation of the project makes it possible to use the created educational resource - the Center for Professional Adaptation of Teachers of the Russian Language of Foreign Schools - in further work: to support the activities of Russian schools abroad, to popularize Russian educational programs, and to form a positive image of Russian science and Russian education. In addition, the work of the Center will contribute to the implementation of state policy in the field of information technology. 


\section{Discussion}

It is logical to present the advanced professional training for teachers of Russian as the second language as a two-stage structure. The first stage concentrates on diagnostic activities. "We believe that the concept of diagnostic testing should be aimed at determination of the vector of professional development of a teacher and be based on two postulates: systematic pattern of performed diagnostic actions and respect of professional independence of a teacher" [25, p. 5]. The second stage is the educational component of the advanced professional training system. In this work, we will focus on the diagnostic activities of the project, involving the assessment (measurement) of the teacher's activities from three standpoints: 1) from the subject knowledge point of view 2) from the organizational and methodological point of view, 3) from the psychological points of view. In this case, the instrument of pedagogical measurement is testing. Let us consider each of these diagnostic components in more detail.

\subsection{Subject competencies are diagnosed using three tests}

Test 1 "Fundamentals of linguistic knowledge" is a closed-type achievement test (multiple-choice answer). It assesses the knowledge component of competencies and contains 60 tasks on the most important sections of linguistics. Test execution time is 30 minutes.

Test 2 "Difficult cases of Russian grammar and Russian word usage" is a closed-type achievement test (multiple-choice answer). It assesses the knowledge component of competencies, contains 60 tasks in the main sections of the Russian language. Test execution time is 30 minutes.

Test 3 "Russian spelling" is a mixed type test. It contains multiple-choice and open answer tasks, assesses graphic, spelling, and other skills and abilities included in the structure of the competence of writing. The test contains 60 tasks on the main sections of spelling, punctuation, speech culture. The execution time is 30 minutes.

Performing this group of tests allows to determine not only highly specialized (subject) knowledge, but also a special kind of subject skills, proficiency, ways of thinking [26].

\subsection{Diagnostics of methodological competencies is carried out through three tests}

Test 1 "Fundamentals of methods of teaching foreign languages and RSL" is a closed-type achievement test (multiple-choice answer), that assesses the knowledge component of competencies, contains 60 tasks on the main sections of methods of teaching foreign languages and RSL. Test execution time is 30 minutes.

Test 2 "Analysis and evaluation of the student's oral performance. Solution of methodological problems" is an open-type situational test that includes 3 tasks in the "analysis of a specific situation" format. It assesses organizational skills, skills of correction and assessment, and other components of methodological sub-competencies. The time to complete one task is 10 minutes, the whole test takes 30 minutes.

Test 3 "Analysis and evaluation of the student's writing. Solution of methodological problems" is an open-type situational test that includes 3 tasks in the "analysis of a specific situation" format. It assesses organizational skills, skills of correction and assessment, and other components of methodological sub-competencies. The time to complete one task is 10 minutes, the whole test takes 30 minutes. 
The implementation of this group of tests allows to identify and measure the level of formation of specific abilities of a teacher, necessary professional activities in a specific subject area. Under "specific abilities" in this case we mean methodological techniques aimed at introducing, consolidating, and training language material in a certain sequence [27]; at forming skills in various types of speech activity and their control, at the organization and management of the learning process. The concept of "methodological competence" also includes theoretical knowledge in the field of methods of teaching foreign languages and complex methodological skills that ensure the implementation of the teacher's basic constructive planning, organizational, and controlling pedagogical functions.

\subsection{Diagnostics of psychological competencies is carried out through three tests}

Test 1 "Fundamentals of psychological knowledge" is a closed-type achievement test (multiple-choice answer) that assesses the knowledge component of competencies. It contains 60 tasks on the most important sections of educational psychology and speech psychology. Test execution time is 30 minutes.

Test 2 "Speech interaction. Solving psychological problems" is an open-type situational test, includes 3 tasks in the "analysis of a specific situation" format. The test assesses organizational, constructive and design, correction, and assessment skills, and other components of psychological sub-competencies. The time to complete one task is 10 minutes, the whole test takes 30 minutes.

Test 3 "The psychological climate of the team. Solving psychological problems" is an open-type situational test, which includes 3 tasks in the "analysis of a specific situation" format. The test assesses organizational, constructive and design, correction, and assessment skills, and other components of psychological sub-competencies. The time to complete one task is 10 minutes, the whole test takes 30 minutes.

The implementation of this group of tests allows the teacher to reveal his knowledge of the mental organization of a personality and the psychological ways of development and formation of human abilities. The tests determine the teacher's bodily-mental potential, his psychological patterns of interaction with other people, psychological means, and ways of people influencing each other, psychological content and factors of communal life, psychological education and culture of communication. All this is included in the content of the professional training of an RSL teacher and should be diagnosed systematically.

This project needs to use questionnaires, which are a valuable source of information about the subjects (teachers of Russian as the second language in Russia and abroad). It is planned to introduce two questionnaires to obtain and confirm objective information: 1) a questionnaire that precedes the diagnostics, and 2) a questionnaire after the completion of the program of the advanced professional training course. The first questionnaire will reveal professional preferences (both individual and segment), which will greatly help in adjusting the created diagnostic tests and professional development programs [20]. The second questionnaire will provide information on the degree of satisfaction/dissatisfaction of the trainees with the course.

Following the traditional rules of testology, questionnaires assume rigidly fixed order, content, and form of questions and a clear indication of the form of answers.

It is advisable to involve groups of participants in diagnostic testing on the cluster principle. In this case, the analyzed diagnostic work and completed questionnaires will become the foundation for developing objective recommendations for creating programs of advanced professional education for teachers working with specific ethnic groups. 
As part of the project, it is planned to develop modular educational programs for advanced education in each of the three areas of activity (subject, organizational and methodological, psychological).

\section{Conclusion}

The system of advanced professional training for teachers of Russian as the second language needs significant updating. This is due to several factors, the main of which is the social requirement of society for a specialist who is competent not only in the subject area but in the field of distance technologies, who can professionally carry out teaching in an open information space. The first stage in the introduction of innovations is the diagnostics of existing teachers of RSL to measure the level of subject, methodological, and psychological competencies. A well-built system of diagnostic measures, considered in the aspect of continuing professional education, can identify competence gaps and help in modeling the educational content of the entire system of an RSL teacher's advanced professional training.

\section{References}

1. Federalnyi zakon ot 29.12.2012 №273-FZ (v red. ot 20.04.2021) “Ob obrazovanii v Rossiiskoi Federatsii" [Federal Law of December 29, 2012, No. 273-FZ (as amended on April 20, 2021) "On Education in the Russian Federation"]. ConsultantPlus. Accessed on: July 21, 2021. [Online]. Available: http://www.consultant.ru/document/cons_doc_LAW_140174/

2. The national program "Digital Economy of the Russian Federation" No. 1632-r (July 28, 2017). Accessed on: April 10, 2021. [Online]. Available: http:/government.ru/rugovclassifier/614/events/

3. A.A. Kuznetsov, T.N. Suvorova, Pedagogy, 1, 94-101 (2016)

4. I.Y. Mishota, RSUH Bulletin. Series "Psychology. Pedagogy. Education", 3(13), 97-106 (2018). https://doi.org/10.28995/2073-6398-2018-3-97-106

5. T.V. Kormilitsyna, Study Experiment in Education, 1, 90-98 (2019)

6. TALIS 2018 Results (Volume I): Teachers and School Leaders as Lifelong Learners, TALIS, OECD Publishing, Paris. 2019. [Online]. Available: https://doi.org/10.1787/1d0bc92a-en

7. TALIS 2018 Results (Volume II): Teachers and School Leaders as Valued Professionals, TALIS, OECD Publishing, Paris. 2020. [Online]. Available: https://doi.org/10.1787/19cf08df-en

8. Positive, High-achieving Students?: What Schools and Teachers Can Do, TALIS, OECD Publishing, Paris. 2021. [Online]. Available: https://doi.org/10.1787/3b9551db-en

9. P.V. Simonov, Questions of Psychology, 6, 44-56 (1989)

10. P.Y. Galperin, Introduction to psychology (University, Moscow,1999)

11. N.F. Talyzina, Management of the process of assimilation of knowledge (Moscow State University, Moscow, 1975)

12. N.F. Talyzina, Methodology and History of Psychology, 2(4), 157-162 (2007) 
13. D. Douglas, Assessing language for Specific Purposes (Cambridge University Press, Cambridge, 2000)

14. S. Ahola, A.A. Basharin, N.I. Bashmakov, et al., Current issues of language testing, in I.Y. Pavlovskaya (ed.), Issue 2 (Publishing house of SPbSU, Saint-Petersburg, 2017)

15. A. O'Keeffe, M. McCarthy, R. Carter, From Corpus to Classroom: language use and language teaching (Cambridge University Press, Cambridge, 2007) https://doi.org/10.1017/CBO9780511497650

16. A. O'Keeffe, P. Pe'rez-Paredes, G. Mark, The impact of usage-based approaches on second language learning and teaching. Cambridge education research reports transforming societies through education (Cambridge University Press, Cambridge, 2020)

17. J. Richards, T. Rodgers, Approaches and Methods in Language Teaching. Second Edition (Cambridge University Press, Cambridge, 2001)

18. C. White. The distance learning of foreign languages: A research agenda. Language Teaching, 39(4), 247-264 (2006). https://doi.org/10.1017/S0261444806003727

19. C. Kramsch, S. Thorne. Foreign language learning as global communicative practice. In D. Block \& D. Cameron (eds.), Globalization and language teaching (Routledge, London, 83-100, 2002)

20. F. Helm. The practices and challenges of telecollaboration in higher education in Europe. Language Learning \& Technology, 19(2), 197-217 (2015).

21. F. Helm. Critical Approaches to Online Intercultural Language Education. In: Thorne S., May S. (eds) Language, Education and Technology. Encyclopedia of Language and Education, 3rd ed. (Springer, Cham, 2017) https://doi.org/10.1007/978-3-319-02237-6 18

22. B.T.M. Wong, K.C. Li. Meeting Diverse Student Needs for Support Services: A Comparison Between Face-to-Face and Distance-Learning Students. In: Li K.C., Tsang E.Y.M., Wong B.T.M. (eds) Innovating Education in Technology-Supported Environments. Education Innovation Series (Springer, Singapore, 2020) https://doi.org/10.1007/978-981-15-6591-5 19

23. M. Cooch, Moodle 2.0 First Look (Packt Publishing, 2010)

24. E.K. Samerkhanova, E.P. Krupoderova, I.V. Panova, Digital resources for organizing the educational process and assessing the achievements of students in a distance format: an overview of digital resources for distance education (Minin University, N. Novgorod, 2020)

25. E.M. Markova, A.A. Pozdnyakova, T.E. Kolyadina, D.D. Dmitriyeva, V.V. Zotov, Integrative potential of educational resources in a modern metropolis, in SHS Web Conf, 98, 03013 (2021). https://doi.org/10.1051/shsconf/20219803013

26. J.-C. Beacco, H.-Jü. Krumm, D. Little, Ph. Thalgott. The Linguistic Integration of Adult Migrants. L'intégration linguistique des migrants adultes. (De Gruyter Mouton, Berlin, Boston, 2017) https://doi.org/10.1515/9783110477498

27. I.Y. Pavlovskaya, O.G. Gorina, Bulletin of the Cherepovets State University, 1, 132-138 (2017). https://doi.org/10.23859/1994-0637-2017-1-76-19 